\title{
Embryonic development and spawning pattern of Trisopterus luscus (Teleostei: Gadidae) under controlled conditions
}

\author{
ALEXANDRE ALONSO-FERNÁNDEZ, ALBA RUTH VERGARA AND FRAN SABORIDO-REY \\ Instituto de Investigaciones Marinas (CSIC), C/Eduardo Cabello 6, Vigo, Pontevedra, E-36208, Spain
}

\begin{abstract}
Knowledge on early ontogeny of Trisopterus luscus is scarce and incomplete. This paper describes the first successful attempt ever at achieving the natural spawning in captivity for this species. The reproductive specimens used for this study were obtained in the Ría de Vigo in September 2008 and subsequently transported to the facilities of the Institute of Marine Research (CSIC). The spawning frequency was variable among females, 1.8-4.6 days, but no size-dependent trend was determined. The average batch size, i.e. the number of eggs released per batch, has proven significantly dependent on female length and weight. In the present study the complete embryonic development in controlled conditions (sand-filtered seawater at $\sim 13^{\circ} \mathrm{C}$, with natural photoperiod), from egg to hatched larva, has been described for the first time ever. The development of pouting eggs was divided into six stages, based on the artificially-reared material. Pouting eggs are pelagic with a smooth, clear and spherical chorion, and a homogeneous yolk. The perivitelline space is narrow and oil globules are absent. Live eggs fertilized were $0.95-1.10 \mathrm{~mm}$ in diameter. The embryo hatches as a yolk-sac larva with closed mouth and gut. The pouting eggs hatched during the latter half of the fifth day.
\end{abstract}

Keywords: Trisopterus luscus, embryonic development, fish eggs, larvae, Galician shelf

Submitted 4 August 2009; accepted 4 January 2010

\section{INTRODUCTION}

The pouting, Trisopterus luscus (Linnaeus, 1758), is a species with a wide distribution across Atlantic waters, occurring from Skagerrak and the British Isles to southern Morocco and the western Mediterranean, preferably in rocky and sandy areas on the continental shelf at depths of $30-100 \mathrm{~m}$ (Wheeler, 1978; Whitehead et al., 1986). Pouting on the Galician shelf has a protracted spawning season, spanning from mid-winter to early spring with a spawning peak between February and April (Alonso-Fernández et al., 2008), which is in agreement with studies conducted on ichthyoplankton in those same waters (Ferreiro \& Labarta, 1988). This teleost of the Gadoid family is of major commercial importance for the artisanal fleet of a number of European countries, but especially for France, Portugal and Spain.

Studies on eggs and larvae of this species are scarce (Ferreiro \& Labarta, 1988; Fox et al., 1997). Despite some existing literature concerning the developmental biology of this species, the description of its embryonic development remains incomplete (Ehrenbaum, 1905-1909; D'Ancona, 1933) and all the data regarding incubation times and embryonic development are exclusively from Erhenbaum (1905-1909). The current work presents the first successful attempt at achieving the natural spawning of pouting in captivity. It is the intent of this paper to contribute to filling the gap of knowledge on the subject by describing and illustrating,

Corresponding author:

A. Alonso-Fernández

Email: alex@iim.csic.es for the first time ever, the development of Trisopterus luscus eggs from spawning to hatching time.

\section{MATERIALS AND METHODS}

The reproductive specimens used for this study were obtained via either of the following methods: (i) hook-and-line techniques performed with conventional recreational gear; or (ii) standard commercial fishery traps set in the Ría de Vigo (Figure 1) in September 2008 and subsequently transported to the facilities of the Institute of Marine Research, in Vigo. The specimens were randomly distributed in two $250 \mathrm{l}$ cylindrical aeration tanks. Both tanks received a constant inflow of sand-filtered seawater at $\sim 13^{\circ} \mathrm{C}$, with natural photoperiod. Before the experiment was started, the fish were allowed to acclimate to these conditions until the beginning of the spawning season (mid-winter-early spring). All specimens were fed to satiation once a day with squid and shrimp during the acclimation and experimental periods.

In December, just before the beginning of the spawning season, the fish were randomly separated in pairs consisting of a female and a male each. The pairs were distributed in six tanks under the same conditions of water flow, photoperiod and feeding regime. Females spawned and males ejaculated in the tanks spontaneously. Tanks were checked and eggs collected and counted on a 24 -hour basis. The ratio between dead eggs and fertilization rate was not assessed during the experimental procedure. Eggs were examined under a stereo microscope (Leica MZ6). Fertilized eggs were transferred to $10 \mathrm{l}$ aquaria with permanent aeration and kept at a constant 


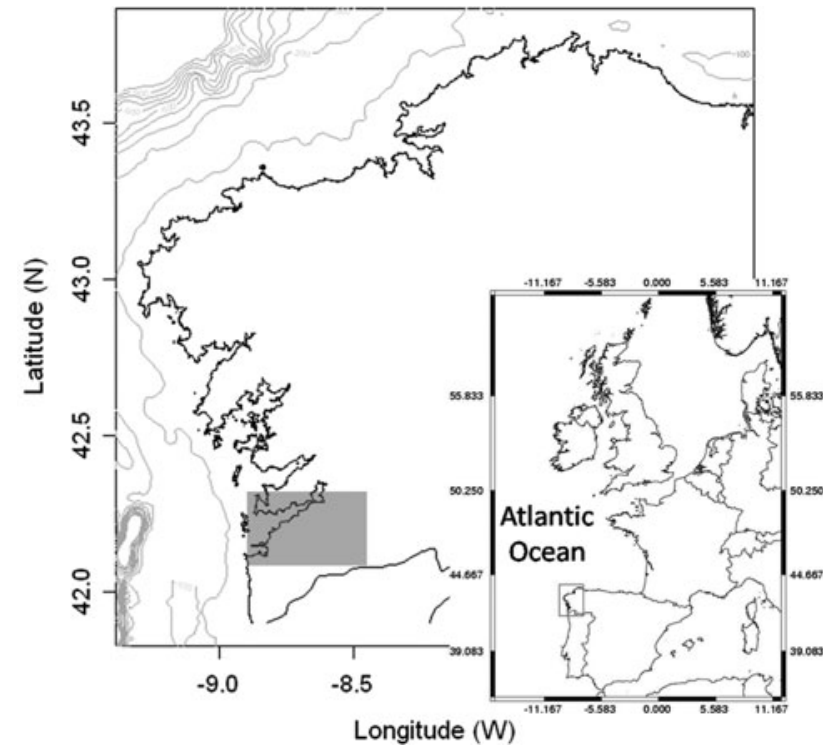

Fig. 1. Pouting (Trisopterus luscus) collection location.

temperature of $13^{\circ} \mathrm{C}$ until hatching. A sample of eggs was removed from the tanks on a 12 -hour basis for the description of their embryonic development stage, and a picture was taken with a video camera connected to the stereo microscope. The embryonic development stages were adapted from the Norway pout (T. esmarki) egg classification, elaborated by Friðgeirsson (1978). All measurements were performed using the software QWin ( $(\mathrm{C}$ Leica Imaging Systems). At the end of the experiment individual spawning frequency was assessed dividing the duration of the spawning activity (total number of days from the first batch released to the last batch recorded) by the total number of batches spawned for each female.

Every female either died or was sacrificed within the first three months after the onset of the spawning season, which therefore could not be tracked fully. Ovaries were removed from all specimens and fixed immediately after in $3.6 \%$ buffered formalin. The central portions of the fixed ovaries were extracted, dehydrated, embedded in paraffin, sectioned at $3 \mu \mathrm{m}$ and stained with haematoxylin-eosin for microscopic analysis.

\section{RESULTS}

\section{Spawning under controlled conditions}

This has been the first successful attempt ever at achieving the natural spawning of pouting in captivity. Coincident with previous studies, the onset of the spawning period for the captive fish took place in early winter, and no hormonal induction was required. Captive female fish spontaneously and repeatedly spawned during the breeding season, even in absence of males.

Despite some individual variation in the spawning frequency, ranging from 1.8 to 4.6 days, no significant $(P>$ 0.05) size-dependent trend could be determined (Table 1). An average amount of one released batch per female every 2.7 days was hence established. Once the females either died or were sacrificed, the histological examinations of their gonads revealed that some of the females remained spawningcapable. This finding thus suggests that the spawning
Table 1. Statistical results for linear models of (i) spawning frequencylength and weight relationships and (ii) batch size-length and weight relationships for pouting, Trisopterus luscus (Linnaeus, 1758).

\begin{tabular}{llllll}
\hline Variable response & Variable explanatory & N & Df & $P$ value & $\mathbf{r}^{2}$ \\
\hline Spawning fraction & Length & 6 & 4 & 0.802 & 0.02 \\
& Weight & 6 & 4 & 0.494 & 0.12 \\
Batch size & Weight & 6 & 4 & 0.004 & 0.90 \\
Ln(batch size) & Ln(length) & 6 & 4 & 0.033 & 0.72 \\
\hline
\end{tabular}

season could extend for longer than three months at an individual level.

Batch fecundity, i.e. the number of eggs released per batch, ranged approximately between 1900 and 80,000 hydrated oocytes (fish length ranged between 20 and $28 \mathrm{~cm}$ ) throughout the experiment. Relative batch fecundity yielded a mean of $51 \pm 15$ (mean $\pm \mathrm{SD}$ ) hydrated oocytes per gram of female throughout the experimental procedure. Batch fecundity-size (length and weight in $\mathrm{cm}$ and g respectively) relationships were evaluated and the correspondent equations are presented below:

$$
\begin{gathered}
\operatorname{Ln}(\text { No. eggs } / \text { batch })=-6.01+4.75 \times \operatorname{Ln}(\text { length }) \\
\text { No. eggs } / \text { batch }=-5069+80 \times \text { weight }
\end{gathered}
$$

The average batch size, i.e. the number of eggs released per batch, was significantly dependent $(P<0.05)$ on length $(\mathrm{cm}$, Equation 1) and weight (g, Equation 2). Parameter estimates for both relationships are listed in Table 1 and fitted models are shown in Figure 2. In Table 2 complete individual spawning data are provided.

\section{Embryonic development of pouting, Trisopterus luscus, at $13^{\circ} \mathrm{C}$}

Recently released pouting eggs are pelagic, with a smooth, clear and spherical chorion, and a homogeneous yolk. The perivitelline space is narrow and oil globules are absent. Live eggs fertilized were $0.95-1.10 \mathrm{~mm}$ in diameter $(\mathrm{N}=160$,

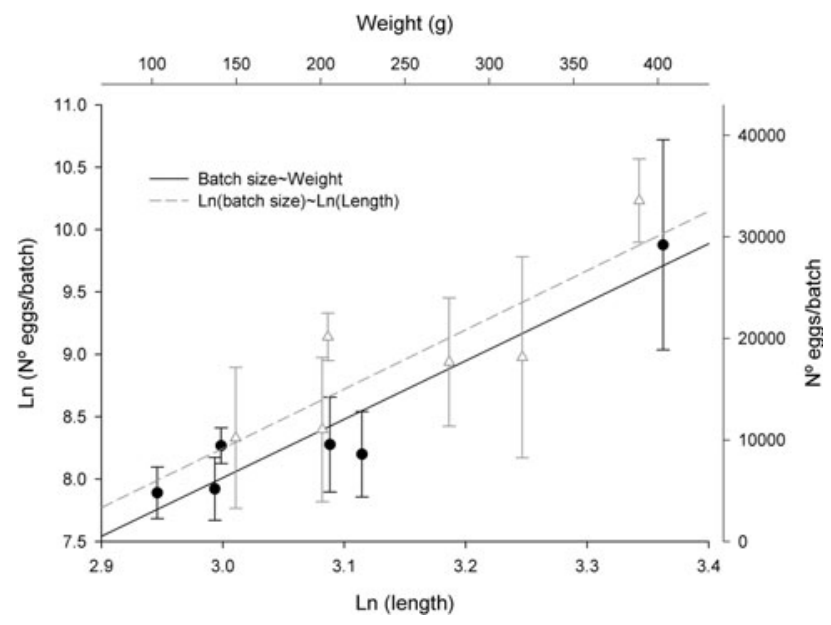

Fig. 2. Fitted curves of average batch size-length (log-transformed) and batch size-weight relationships. Grey triangles correspond to batch size-length (log-transformed) relationship and black dots batch size-weight relationship. 
Table 2. Individual spawning data of the pouting, Trisopterus luscus (Linnaeus, 1758), in captive conditions at $13^{\circ} \mathrm{C}$. Batch size expressed as number of eggs released per batch, spawning frequency as average elapsed time in days between batches and egg diameter in microns.

\begin{tabular}{|c|c|c|c|c|c|}
\hline Fish & Length (cm) & Weight (g) & $\begin{array}{l}\text { Batchsize } \\
\text { Mean } \pm \text { SD }\end{array}$ & Spawning frequency & $\begin{array}{l}\text { Egg diameter } \\
\text { mean } \pm S D\end{array}$ \\
\hline 1 & 28 & 403 & $29211 \pm 10338$ & 2.0 & $1019 \pm 21$ \\
\hline 2 & 24 & 225 & $8588 \pm 4200$ & 1.8 & $1041 \pm 18$ \\
\hline 3 & 22 & 141 & $9430 \pm 1768$ & 2.3 & $1035 \pm 22$ \\
\hline 4 & 22 & 137 & $5182 \pm 3102$ & 4.6 & $1016 \pm 18$ \\
\hline 5 & 26 & 206 & $9541 \pm 4662$ & 3.5 & $1051 \pm 34$ \\
\hline 6 & 20 & 103 & $4789 \pm 2552$ & 2.2 & $1010 \pm 23$ \\
\hline
\end{tabular}

mean $1.03 \mathrm{~mm}, \mathrm{SD} 0.03 \mathrm{~mm}$ ), showing scant variation in their development stage. No manipulation was required for egg fertilization: the released eggs were naturally fertilized in the tanks. The development of pouting eggs was divided into six stages, based on the artificially-reared material. A detailed description of each development stage is provided below and Table 3 provides information on timing at each stage and organogenesis.

Stage 1. Fertilization-preparation for cleavage (precell-early stage)

The egg is quite transparent. Cell division has not yet begun. Cytoplasm is concentrated at the animal pole, appearing as a raised cap of undivided cellular material, easily differentiated from the yolk mass (blastodisc: preparation for cleavage) (Figure $3 \mathrm{~A}$ ). The membrane is thin and a small content of carotin gives the egg a faint yellow hue. This, together with the small size of the egg, makes it almost invisible in the water to the naked eye.

Stage 2. Cleavage of the blastodisc

The cleavage of the blastodisc begins with the division of the single cell into two daughter cells (blastomeres), becoming multicellular by repeated cleavages:

2 cells-Cleavage 1 . Cytoplasm splits into two equal-sized cells (Figure $3 \mathrm{~B}$ ).

4 cells-Cleavage 2 . Cell cap consists of four cells of equal size

(Figure ${ }_{3} \mathrm{C}$ ).

Table 3. Embryonic development of the pouting, Trisopterus luscus (Linnaeus, 1758 ), at $13^{\circ} \mathrm{C}$.

\begin{tabular}{|c|c|c|c|}
\hline \multicolumn{2}{|c|}{ Mean duration } & \multirow[t]{2}{*}{ Stage } & \multirow[t]{2}{*}{ Description } \\
\hline Hours & Minutes & & \\
\hline oo & oo & Fertilization & \\
\hline $01^{*}$ & оo & 1 & $\begin{array}{l}\text { Preparation for cleavage } \\
\text { (precell-early stage) }\end{array}$ \\
\hline 07 & 13 & 2 & Cleavage of the blastodisc \\
\hline 25 & 57 & 3 & $\begin{array}{l}\text { Formation of basic embryonic } \\
\text { tissue layers-gastrulation }\end{array}$ \\
\hline 33 & 37 & 4 & $\begin{array}{l}\text { Formation of pre-organs- } \\
\text { organogenesis } 1\end{array}$ \\
\hline 75 & 30 & 5 & $\begin{array}{l}\text { Full development of } 171 \text { main } \\
\text { organs-organogenesis } 2\end{array}$ \\
\hline 100 & 41 & 6 & Preparation for hatching \\
\hline 108 & 55 & 7 & Hatching \\
\hline
\end{tabular}

*, mean duration taken by Friðgeirsson (1978).
8 cells-Cleavage 3 . Eight cells in 2 parallel rows form a singlelayer rectangle (Figure $3 \mathrm{D}$ ).

16 cells-Cleavage 4. Fourth and last division of cells on a single layer. Cells form a rough square, four cells wide and four cells long (Figure $3 \mathrm{E}$ ).

$>_{16}$ cells. After the 5 th or 6 th division, the blastodisc attains a berry-like appearance that is oftentimes referred to as the 'mulberry stage' (Moser \& Ahlstrom, 1985) (Figure ${ }_{3} \mathrm{~F}$ ). During all of the aforementioned stages, cells multiply and become smaller. However, the size of the blastodisc remains constant. The result of this process is a regular morula (Figure $3 \mathrm{G}, \mathrm{H}$ ).

The border of the morula thickens and forms the germ ring of the blastula (Figure 4A, B).

\section{Stage 3. Formation of basic embryonic tissue} layers-gastrulation

The formation of the basic embryonic tissue layers marks the beginning of gastrulation (Figure $4 \mathrm{C}$ ). The beginning of this stage is best defined by the visual aspect of the blastoderm, which resembles tissue rather than a collection of individual cells. The margin of the blastodisc becomes slightly thickened and is termed the germ ring. On one region of the germ ring the thickening extends inwards to form the embryonic shield, which defines the future axis of the embryo.

Gastrulation proceeds by further proliferation and downward movement of the cells in the region of the germ ring by a process known as epiboly, i.e. the expansion of the cellular blastoderm over the yolk. At the end of this stage, the germ ring has enclosed one-third of the yolk mass and the embryo is beginning to form along the median region of the embryonic shield. The head region of the embryo is becoming apparent (Figure $4 \mathrm{D}$ ).

Stage 4. Formation of pre-organs-organogenesis Formation of the first rudimentary organs marks the end of gastrulation and the beginning of organogenesis. During this stage, the head and part of the embryonic body are formed.

This stage is characterized by the development of the notochord, which can be seen from a dorsal viewpoint, and the differentiation of the optic vesicles from the brain (the optic bulbs; Figure $4 \mathrm{E}$ ). Subsequently, the germ ring has closed, has almost completed overgrowth of the yolk, but the blastopore remains open.

The ear primordia have formed and can be seen on both sides of the hindbrain (Figure $4 \mathrm{~F}$ ). The embryo has expanded over approximately one-half of the yolk sac circumference. Subsequently, the blastopore becomes closed. 


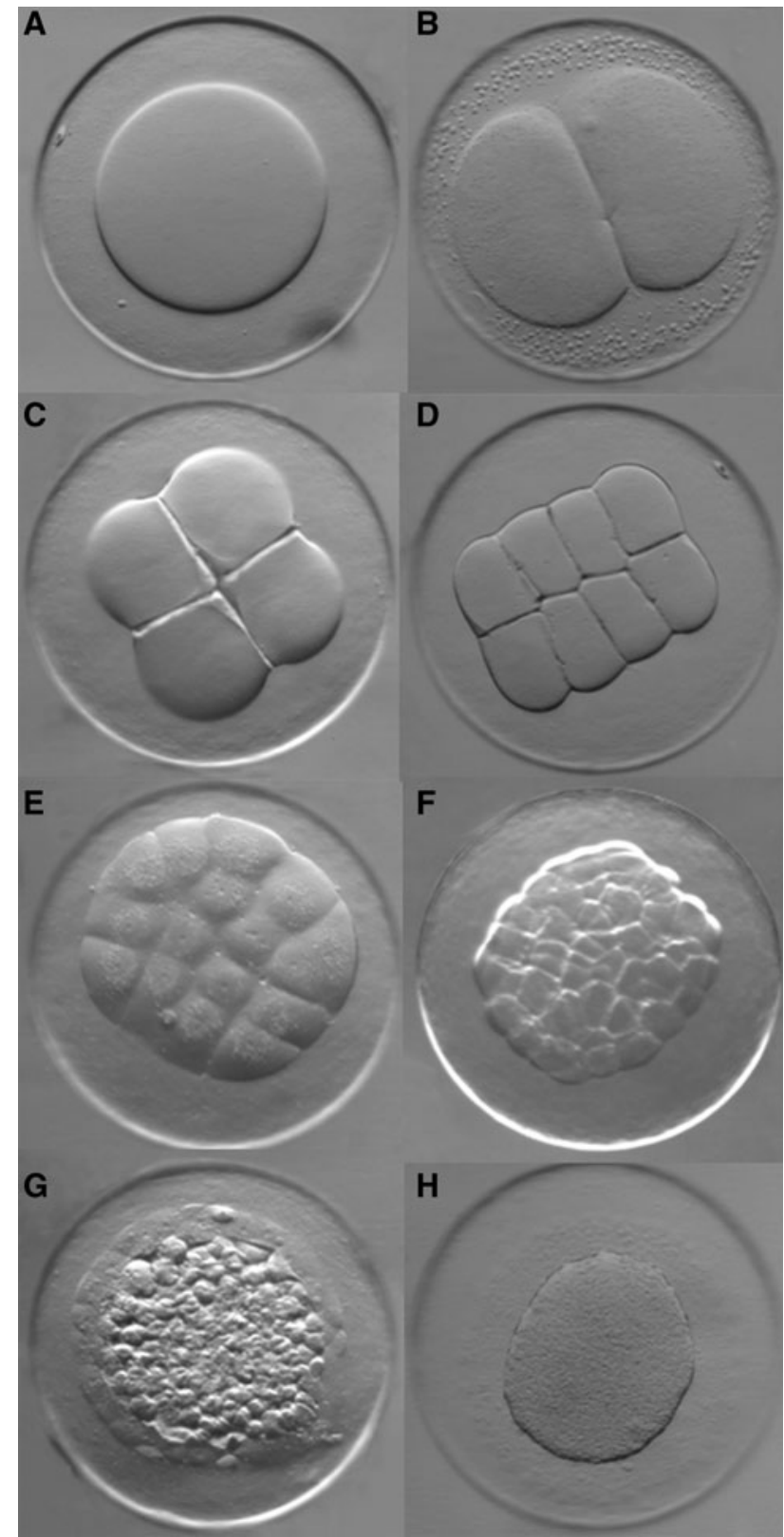

Fig. 3. Development stages of eggs of pouting, Trisopterus luscus, reared from known adults at $13^{\circ} \mathrm{C}$. (A) Stage 1 ; (B) Stage 2 (2 cells); (C) Stage 2 (4 cells); (D) Stage 2 ( 8 cells); (E) Stage 2 ( 16 cells); (F) Stage 2 (>16 cells, 'mulberry'); (G) Stage 2 (morula); (H) Stage 2 (morula). Photographs by A. A-F.

At the time of the closure of the blastotopore, the first pigmentation of the embryonic body begins (Figure $4 \mathrm{G}$ ). First somites have been formed at the middle of the embryonic body. The tail is plump and the tip appears to be lifting from the yolk surface, but the tail margin is still attached (Figure $4 \mathrm{H}$ ).

Stage 5. Full development of main organs - organogenesis 2 During the second part of the organogenesis, the organs and systems of organs become functional one after another. The head and tail regions of the embryo are discernible. The tail is developing. This stage begins when the tail starts separating from the yolk mass (Figure 5A, B). Initially, the tail is broadly rounded and then begins to narrow as it rapidly elongates. On

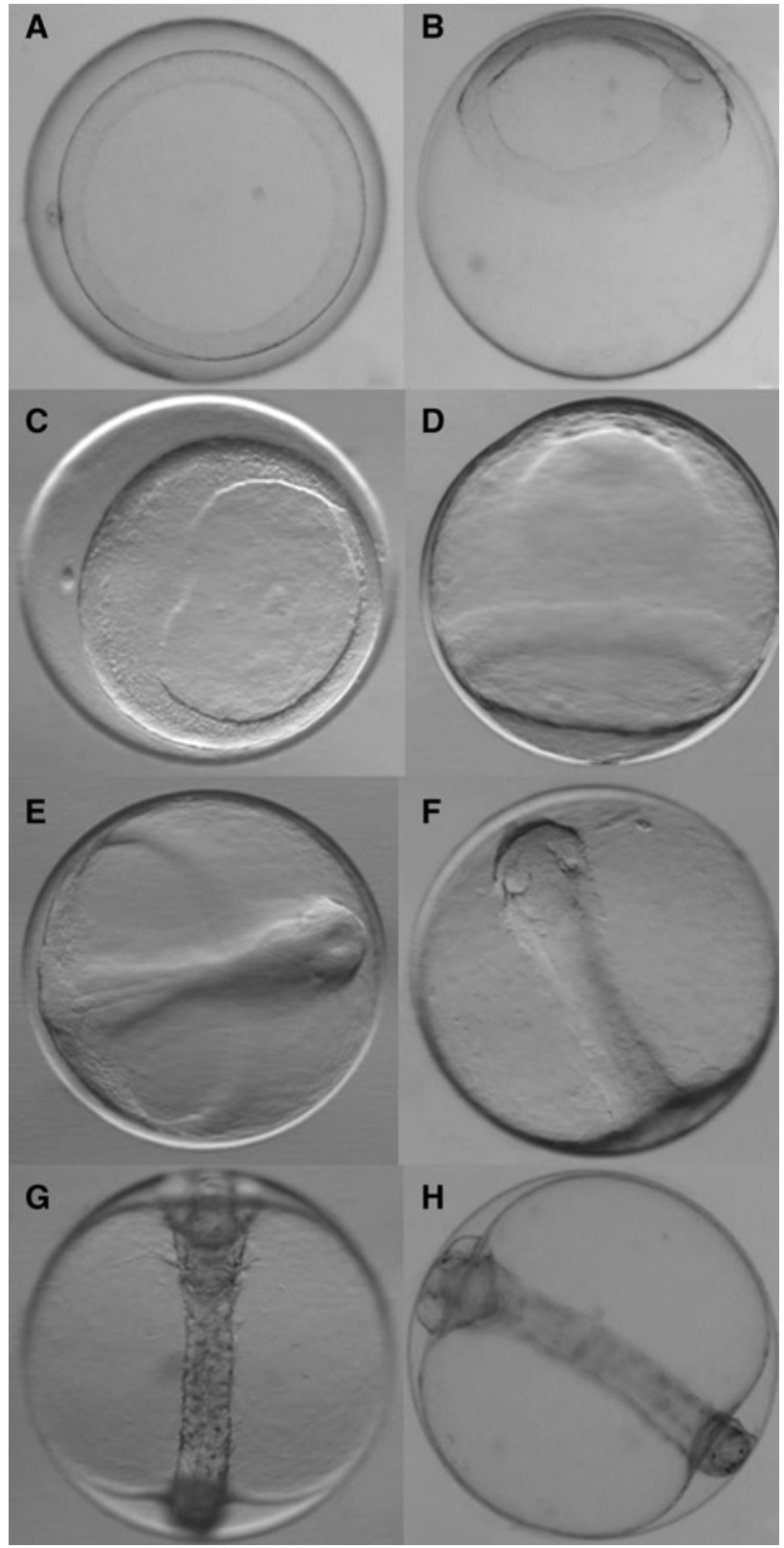

Fig. 4. Development stages of eggs of pouting. (A) Stage 2 (blastula); (B) Stage 2 (blastula); (C) Stage 3 (beginning of gastrulation); (D) Stage 3 (late); (E) Stage 4; (F) Stage 4; (G) Stage 4; (H) Stage 4 (late). Photographs by A. A-F.

both sides of the embryonic body, the rudimentary pectoral fin lobes are taking shape and myomeres are clearly visible (Figure $5 \mathrm{C}$ ). Fin lobes are developing ventrally and dorsally on the tail and on the dorsal side of the embryonic body (Figure $5 \mathrm{C}, \mathrm{D}$ ).

\section{Stage 6. Preparation for hatching}

The beginning of the preparation for hatching marks the end of the organogenesis (Friðgeirsson, 1978). This is the final stage before hatching and it is defined by an embryo length exceeding three-quarters of the egg's circumference. It lasts until the tail reaches the head (Figure ${ }_{5} \mathrm{E}, \mathrm{F}$ ). The tail is well separated from the yolk mass and the rest of the embryo remains tightly associated with the yolk. The tail continues to separate from the yolk as the embryo grows. 


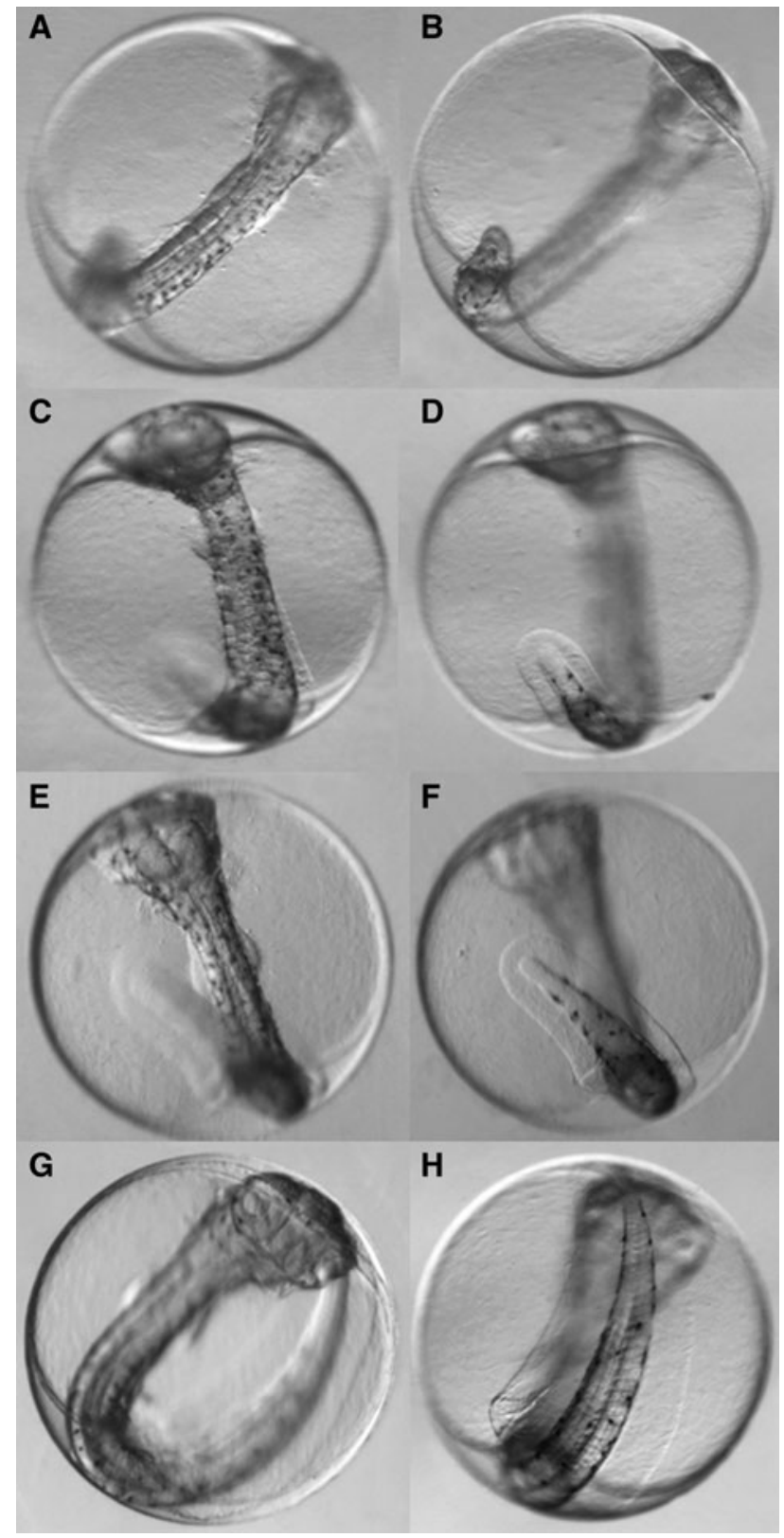

Fig. 5. Development stages of eggs of pouting. (A) Stage 5; (B) Stage 5; (C) Stage 5; (D) Stage 5 (late); (E) Stage 6; (F) Stage 6; (G) Stage 6; (H) Stage 6 (before hatching). Photographs by A. A-F.

Late stage: the tail completes a full circle around the upper half of the yolk. The tail of the embryo almost touches the head (Figure $5 \mathrm{G}, \mathrm{H}$ ). Pupils can be discerned in the eyes, optic cups remain unpigmented (Figure 5G). Embryo pigment intensifies, including melanophores over the snout, and additional melanophores develop laterally along the trunk and tail.

\section{Stage 7. Hatching}

The embryo hatches as a yolk-sac larva with closed mouth and gut. The head has not yet lifted from the yolk sac (Figure 6A). The pouting eggs hatch during the latter half of the fifth day ( $4.54 \pm 0.17$ days, approximately).

The yolk-sac is large and facing upwards, and the embryo is floating on its surface. The newly hatched larva is $3.13 \mathrm{~mm} \pm$

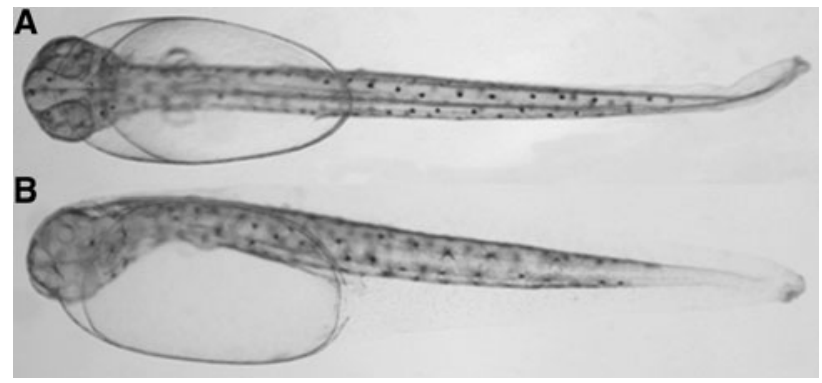

Fig. 6. Newly-emerged yolk-sac larva of pouting, emerged after 109 hours of rearing at $13^{\circ} \mathrm{C}$. (A) Ventral view of larva; (B) $3.18 \mathrm{~mm}$ body length. Photographs by A. A-F.

0.15 SD long. Eyes still almost unpigmented. The whole body shows black star-shaped chromatophores (Figure 6B). The farthest third of the postanal portion of the body is free from pigment.

Numerous minute yellow chromatophores were distributed over the whole of the body, yolk-sac and primordial fin (Figure 6B). These chromatophores provided the larva with a dim yellowish gleam.

Previously published characteristics of eggs and yolk-sac larvae of the pouting are presented in Table 4 to facilitate comparisons with those derived in the present study (Table 4). Also comparative data for eggs and yolk sac larvae for $T$. luscus and other species from genus Trisopterus are shown in Table 5.

Table 4. Characteristics of eggs and yolk-sac larvae of the pouting, Trisopterus luscus (Linnaeus, 1758).

\begin{tabular}{|c|c|c|c|}
\hline $\begin{array}{l}\text { Egg } \\
\text { diameter } \\
(\mathrm{mm})\end{array}$ & $\begin{array}{l}\text { Incubation } \\
\text { (days) }\end{array}$ & $\begin{array}{l}\text { Yolk-sac } \\
\text { larvae }(\mathrm{mm})\end{array}$ & Source \\
\hline $\begin{array}{l}0.97(0.90)- \\
1.23\end{array}$ & $10-12$ & 3.0 & Ehrenbaum, 1905-1909 \\
\hline $\begin{array}{l}0.97(0.90)- \\
1.23\end{array}$ & $10-12$ & 3.0 & $\begin{array}{l}\text { Ehrenbaum, 1905-1909 } \\
\text { cited by D'Ancona, } 1933\end{array}$ \\
\hline $1.07-1.23$ & $10-12$ & 3.0 & $\begin{array}{l}\text { Ehrenbaum, 1905-1909 } \\
\text { cited by Russell, } 1976\end{array}$ \\
\hline $0.89-1.10$ & & & Ferreiro, 1985 \\
\hline $0.9-1.23$ & & & Nichols et al., 1993 \\
\hline $0.9-1.23$ & & & Fox et al., 1997 \\
\hline $0.9-1.23$ & & $\sim 3.0$ & Ré, 1999 \\
\hline $0.95-1.10$ & $4.54 \pm 0.17$ & $3.13 \pm 0.15$ & This work \\
\hline
\end{tabular}

Table 5. Comparative data for eggs and yolk-sac larvae for T. luscus and other species from genus Trisopterus.

\begin{tabular}{llll}
\hline Species & $\begin{array}{l}\text { Egg } \\
\text { diameter } \\
(\mathbf{m m})\end{array}$ & $\begin{array}{l}\text { Yolk-sac } \\
\text { larvae } \\
(\mathbf{m m})\end{array}$ & Source \\
\hline Trisopterus & $0.90-1.22$ & 3.0 & $\begin{array}{l}\text { Russell, 1976 cited } \\
\text { by Dunn \& Matarese, }\end{array}$ \\
& & & $\begin{array}{l}1984 \\
\text { T. esmarkii }\end{array}$ \\
$\begin{array}{l}\text { T. minutus } \\
\text { T. luscus }\end{array}$ & $0.95-1.03$ & 3.2 & Russell, 1976 \\
T. luscus & $0.90-1.23$ & 3.0 & \\
\hline
\end{tabular}




\section{DISCUSSIDN}

The present paper aims to contribute to the study of the spawning of one of the fish species with the highest commercial importance for the artisanal fisheries of several European countries, primarily France, Portugal and Spain. Morphological identification and correct ageing of pelagic eggs in ichthyoplankton surveys is crucial in the egg production method (Moser \& Ahlstrom, 1985), and despite pouting being a determinate spawner (Alonso-Fernández et al., 2008), the biological information provided in this paper could help to estimate realized annual fecundity (Murua \& Saborido-Rey, 2003).

The presence of pelagic eggs of pouting on the Galician shelf (north-western Spain) was associated with the colder months of the year $\left(12-14^{\circ} \mathrm{C}\right)$, while salinity was relatively constant, around $35 \%$ (Ferreiro, 1985). Therefore, the highest egg densities for Trisopterus luscus were found during icthyoplankton cruises in the Ría of Vigo in winter and spring (Ferreiro \& Labarta, 1988), in agreement with the spawning season data described in some studies on the Iberian shelf (Labarta et al., 1982; Merayo, 1996; Alonso-Fernández et al., 2008). Pouting's peak reproductive activity seems to vary with latitude, from December to April on the Asturian coast (Merayo 1996), from January to March on the coast of Brittany (Gherbi-Barre, 1983), from February to June in the English Channel, and in March in the North Sea (Desmarchelier, 1985). Larvae began to appear in significant numbers in the eastern Irish Sea from early April onwards (Nichols et al., 1993; Fox et al., 1997), a little bit later than on the Galician shelf due to spawning season delay. This study was the first attempt at achieving the reproduction in captivity of this species. Poutings spontaneously spawned successful batches of viable eggs in controlled conditions; artificial hormonal induction was not necessary. The average spawning frequency estimated at an individual level during the experiment was of 3 days. This result was inferior to the average spawning frequency assessed at a population level on the Galician shelf (north-western Spain) (Alonso-Fernández et al., 2008), which was approximately of $6-7$ days. The disparities found between captivity and field studies might be due to the different approaches used: individual level versus population. Additional likely sources of variation could be the effects of capture, confinement and repeated sampling, which generate stress in captive fish. Stress is known to cause a variety of physiological responses in fish, affecting fecundity, egg size and egg survival, and spawning behaviour (Morgan et al., 1999). The duration of the spawning season seems to be consistent with field studies (Labarta et al., 1982; Merayo, 1996; AlonsoFernández et al., 2008). Captive pouting corroborates the observations in the wild concerning a protracted spawning season, longer than 3 months even at an individual level. Nonetheless, results concerning this respect should be carefully interpreted, since the spawning season was not fully tracked for any of the individuals studied in the experiment. As expected, batch fecundity proved to be significantly dependent on length and weight, and the average relative batch fecundity, i.e. the number of released eggs per batch and gram of female, was quite similar to the one estimated in field studies (Alonso-Fernández et al., 2008), namely 51 and $46 \mathrm{eggs} / \mathrm{g}$ respectively.

The development of pouting eggs was divided into six stages, based on the artificially reared material and adapted from Friðgeirsson (1978). The embryonic development sequence described in this paper is consistent with previous studies on Trisopterus luscus (Ehrenbaum, 1905-1909) and the egg classification for Trisopterus esmarki (Nilsson) (Friðgeirsson, 1978). The temperature selected for the experimental period, $13^{\circ} \mathrm{C}$, was on par with the typical conditions of surface water in late winter on the Galician shelf (Domínguez-Petit, 2008). Additionally, the prevalence of pouting eggs is higher in Galician waters at temperature ranges between $12^{\circ}$ and $14^{\circ} \mathrm{C}$ for that period (Ferreiro, 1985). Under artificially controlled conditions at a constant $13^{\circ} \mathrm{C}$, hatching time was estimated in approximately $4.54 \pm$ 0.17 days, while Ehrenbaum (1905-1909) determined this period to be 10-12 days in the south-western North Sea. However, no reference temperature was provided by Ehrenbaum (1905-1909) in his studies. Friðgeirsson (1978) found that $T$. esmarki hatches after 5 days and 20 hours of incubation at $7.2^{\circ} \mathrm{C}$. The disparities between this study and Ehrenbaum's observations could be due to differences concerning incubation temperature, since fertilized eggs came from northern waters containing reared material. It has been clearly demonstrated for several species that egg development is strongly temperature-dependent, and the decrease of the developmental time for higher temperatures is known for a number of fish species (Blaxter, 1969; Miranda et al., 1990; Cunha et al., 2008). Thus, further research is needed to properly ascertain pouting's developmental rates for the likely temperature range at different latitudes.

Eggs float due to their high water content, nearing $90 \%$ as for other species from the same genus (Friðgeirsson, 1978). Due to an egg mean diameter of $0.95-1.10 \mathrm{~mm}$ as per the results of the present study, the identification of pouting eggs could be problematic given their similarities to other species. Pouting eggs cannot be readily separated from those of similar size with no oil globules. In Galician waters, the main sources of identification problems are Trisopterus minutus (Ferreiro, 1985) and Pollachius pollachius. In northern latitudes, however, Merlangius merlangus, Platicthys fesus and Limanda limanda can also be misleading (Fox et al., 1997). Regarding egg and larvae size, the present results are similar to those found in previous studies. Ferreiro (1985) found eggs with $0.89-1.10 \mathrm{~mm}$ of diameter, which is consistent with our own findings, while Erhenbaum (1905-1909) and Russell (1976) established the diameter-range of fertilized eggs to be between $0.97-1.23$ and $0.90-1.22 \mathrm{~mm}$ respectively, i.e. they found larger eggs. Nichols et al. (1993), Fox et al. (1997) and Ré (1999) determined the egg diameter-range to be between 0.90 and $1.23 \mathrm{~mm}$, in accordance with the latter references. Hatched larvae, measured within the first 24 hours after hatching, were $3.13 \mathrm{~mm} \pm 0.15$ SD long. Ferreiro (1985) and Erhenbaum (1905-1909) described hatched larvae as slightly below $3.0 \mathrm{~mm}$ long. Larvae of T. luscus are quite similar to those of Micromessistius poutassou but they can be easily distinguished by the number of miomeres, namely $48-49$ and 56-60 respectively (Ré, 1999).

The development of the pelagic eggs and hatched larvae of Trisopterus luscus (Linnaeus, 1758) has been described in this study for the first time ever. The experiment has been based on reared eggs from adults captured on the Galician shelf of north-western Spain. This has also been the first natural spawning experience in captivity for this species and it opens a new way for experimental design. Spontaneous 
spawning activity was observed and viable and fertilized eggs obtained through the experimental procedure. The authors expect this study on embryonic development to be useful in future ichthyoplankton surveys for the correct identification of Trisopteurs luscus eggs and hatched larvae, being nevertheless highly desirable that it be complemented by future research with the description of the late larval and early juvenile stages of this species.

\section{ACKNOWLEDGEMENTS}

We would like to thank L. Alonso-Martínez and C. Sánchez-Espinel for providing the specimens for this work. We are grateful to A. Chamorro and R. Chamorro for their helpful fish husbandry advice and also to D. Fernández-Taboada for help with the English and editing. We appreciate anonymous referees' comments on the manuscript. This research was funded by the regional government of Galicia (Xunta de Galicia) under the coverage of Project DETEPRE (o8MMA010402PR).

\section{REFERENCES}

Alonso-Fernández A., Domínguez-Petit R., Bao M., Rivas C. and Saborido-Rey F. (2008) Spawning pattern and reproductive strategy of female pouting Trisopterus luscus (Gadidae), on the Galician shelf of north-western Spain. Aquatic Living Resources 21, 383-393.

Blaxter J.H.S. (1969) Development: eggs and larvae. In Hoar W.S. and Randall D.J. (eds) Fish physiology, Volume III: Reproduction and growth. Bioluminiscence, pigments, and poisons. New York: Academic Press, pp. 175-252.

Cunha M.E., Vendrell C. and Gonçalves P. (2008) Experimental study of the dependence of embryonic development of Trachurus trachurus eggs on temperature. ICES Journal of Marine Science 65, 17-24.

D’Ancona U. (1933) Gadidae. Eggs, larvae and juvenile stages of teleostei. In Lo Bianco S. (ed.) Fauna and flora of the bay of Naples. Stazione Zoologica di Napoli, pp. 188-260.

Desmarchelier M. (1985) Growth and reproduction of the whiting pout (Trisopterus luscus L., 1758) in the English Channel and in the south of the North Sea. ICES CM1985/G, 29.

Domínguez-Petit R., Korta M., Saborido-Rey M., Murua H., Sainza M. and Piñeiro P. (2008) Changes in size at maturity of European hake Atlantic populations in relation with stock structure and environmental regimes. Journal of Marine Systems 71, 260-278.

Dunn J.R. and Matarese A.C. (1984) Gadidae: development and relationships. In Ontogeny and systematics of fishes. American Society of Ichthyologists and Herpetologists, Special Publication No. 1, pp. 283-299.

Ehrenbaum E. (1905-1909) Eier und Larven von Fischen. Nordisches Plankton 1, 413.

Ferreiro M.J. (1985) Ictioplancton de la Ría de Vigo. Doctoral thesis. University of Santiago de Compostela, $563 \mathrm{pp}$.

Ferreiro M.J. and Labarta U. (1988) Distribution and abundance of teleostean eggs and larvae on the NW coast of Spain. Marine Ecology Progress Series 43, 189-199.
Fox C.J., Dickey-Collas M. and Winpenny A.J. (1997) Spring plankton surveys of the Irish Sea in 1995: the distribution of fish eggs and larvae. Science Series Technical Report, 104. Lowestoft, UK: Centre for Environment, Fisheries \& Aquaculture Science (CEFAS), 106 pp.

Friðgeirsson E. (1978) Embryonic development of five species of gadoid fishes in Icelandic waters. Rit Fiskideildar Hafrannsóknastofnunin, Rwykjavík. V. Bindi 5, 3-44.

Gherbi-Barre A. (1983) Biologie de Trisopterus luscus L. de la baie de Douarnenez (Reproduction, Croissance, Régime alimentaire). Doctoral thesis. University of Brest, $92 \mathrm{pp}$.

Labarta E., Ferreiro M.J., Fenandez M.T. and Martinez F. (1982) Spawning season and first maturity size and age of the Galician coast pouting (Trisopterus luscus L.). ICES CM1982/G: 64 .

Merayo C.R. (1996) Reproducción y fecundidad de la faneca Trisopterus luscus (Linnaeus, 1758) (Pisces, Gadidae) en la región central del mar Cantábrico. Boletin del Instituto Español de Oceanografía 12, 17-29.

Miranda A., Cal R.M. and Iglesias J. (1990) Effect of temperature on the development of eggs and larvae of sardine Sardina pilchardus Walbaum in captivity. Journal of Experimental Marine Biology and Ecology 140, 69-77.

Morgan M.J., Wilson C.E. and Crim L.W. (1999) The effect of stress on reproduction in Atlantic cod. Journal of Fish Biology 24, 477-488.

Moser H.G. and Ahlstrom E.H. (1985) Staging anchovy eggs. In Lasker R. (ed.) An egg production method for estimating spawning biomass of pelagic fish: application to the northern anchovy, Engraulis mordax. NOAA Technical Report NMFS 36. US Department of Commerce, Washington, DC, p. 99.

Murua H. and Saborido-Rey F. (2003) Female reproductive strategies of marine fish species of the North Atlantic. Journal of Northwest Atlantic Fishery Science 33, 23-31.

Nichols J.H., Haynes G.M., Fox C.J., Milligan S.P., Brander K.M. and Chapman R.J. (1993) Spring plankton surveys of the Irish Sea in 1982, 1985, 1987, 1988, and 1989: hydrography and the distribution of fish eggs and larvae. MAFF Fisheries Research Technical Report, No. 95, 111 pp.

Ré P. (1999) Ictioplâncton estuarino da Península Ibérica guia de identificação dos ovos e estados larvares planctónicos. Doctoral thesis. University of Lisbon, $114 \mathrm{pp}$.

Russell F.S. (1976) The eggs and planktonic stages of British marine fishes. London: Academic Press, 524 pp.

Wheeler A. (1978) Key to the fishes of Northern Europe, a guide to the identification of more than 350 species. London: Frederick Warne.

and

Whitehead P.J.P., Bauchot M.L., Hureau J.C., Nielsen J. and Tortonese E. (eds) (1986) Fishes of the north-eastern Atlantic and the Mediterranean. Paris: UNESCO.

\section{Correspondence should be addressed to:}

A. Alonso-Fernández

Instituto de Investigaciones Marinas (CSIC)

C/Eduardo Cabello 6, Vigo

Pontevedra, E-36208, Spain

email: alex@iim.csic.es 